\title{
СОЦИАЛЬНАЯ ФРУСТРИРОВАННОСТЬ И ВЫРАЖЕННОСТЬ НЕВРОТИЧЕСКИХ СОСТОЯНИЙ У МОЛОДЫХ ЛЮДЕЙ - АКТИВНЫХ ПОЛЬЗОВАТЕЛЕЙ ИГРОВЫМИ ИНТЕРНЕТ-ПОРТАЛАМИ
}

\section{SOCIAL FRUSTRATION AND EXPRESSION OF NEUROTIC STATES IN YOUNG PEOPLE - ACTIVE USERS OF GAME INTERNET PORTALS}

\section{T. Shevelenkova}

Summary: The prevalence and severity of neurotic states in young people 18-27 years old - active users of Internet gaming portals - were studied: $79.9 \%$ found various neurotic states, and $61 \%$ revealed their painful nature. The most common are neurotic depression and obsessive-phobic disorders, least often asthenia. It is shown that the respondents who are most involved in computer games reveal more pronounced neurotic states. Strong enthusiasm for the Internet $(1.5 \%)$ is typical only for users with a high degree of severity of neurotic states. The question is being discussed whether we are dealing with a new type of pathology - Internet addiction, or whether we are faced with a pathomorphosis of gambling addiction associated with impairment of drives and known from ancient times. It is suggested that the pathomorphosis of neurotic states under the influence of digital technologies can be considered as manifested, in particular, in the intensification of the severity of neurotic states in young people with a sufficiently high degree of involvement in computer games. It is shown that social frustration is characteristic of all respondents, regardless of whether they have neurotic states. The structure of the value orientations of this group of respondents has been determined: the importance of their own health and work capacity comes first, the second - the relationship with the social environment, the third and fourth divide the social status and their own economic position, and the last - the relationship with loved ones.

Keywords: neurotic states, social frustration, passion for the internet.

\author{
Шевеленкова Татьяна Дмитриевна \\ К.nсх.н., доцент, Российский государственный \\ гуманитарный университет, г. Москва; Институт \\ психологии им. Л.С. Выготского \\ shevelenkova@gmail.com
}

Аннотация: В статье была исследована распространенность и выраженность невротических состояний у молодых людей 18-27 лет - активных пользователей игровыми интернет-порталами: 79,9\% обнаружили различные невротические состояния, а $61 \%$ выявили их болезненный характер. Наиболее распространены невротическая депрессия и обсессивно-фобические нарушения, реже всего - астения. Показано, что респонденты, наиболее вовлеченные в компьютерные игры, выявляют более выраженные невротические состояния. Сильная увлеченность Интернет $(1,5 \%)$ характерна лишь для пользователей с высокой степенью выраженности невротических состояний. Обсуждается вопрос о том, имеем ли мы дело именно с новым видом патологии - интернет-зависимостью, либо сталкиваемся с патоморфозом игровой зависимости, связанной с нарушением влечений, и известной с древнейших времен. Выдвигается предположение о том, что патоморфоз невротических состояний под влиянием цифровых технологий можно рассматривать как проявляющийся, в частности, в усилении выраженности невротических состояний у молодых людей с достаточно высокой степенью вовлеченности в компьютерные игры. Показано, что социальная фрустрированность характерна для всех респондентов независимо от наличия у них невротических состояний. Определена структура ценностных ориентаций данной группы респондентов: на первое место выходит значимость собственного здоровья и работоспособности, на второе - отношения с социальным окружением, третье и четвертое делят социальный статус и собственное экономическое положение, а последнее - отношения с близкими.

Ключевые слова: невротические состояния, социальная фрустрированность, увлеченность Интернет.
$\mathrm{B}$ конце XX - начале XXI веков значительно изменился социальный и культурный ландшафт нашей эпохи: возникает множество социальных, политических, экономических и других изменений, оказывающих существенное влияние на психическое здоровье человека $[8 ; 9 ; 11 ; 12 ; 15]$.

Последствием глобальных экономических и политических сдвигов в российском обществе стало резкий рост числа так называемых социально-стрессовых расстройств, составляющих группу нарушений психической адаптации, к которым были отнесены и неврозы [3; 5; 10]. Социально-стрессовые расстройства возникают вследствие общей идеолого-ценностной дезориентации и актуализации макросоциальных проблем, дезорганизующих и дестабилизирующих психическое состояние человека за счет «таких факторов, как непрогнозируемость и неподконтрольность событий, неопределенность жизненного положения, незащищенность перед угрозой, необратимость изменений и т. п.» [5, с. 367].

Макросоциальные и микросоциальные факторы оказывают влияние на процесс формирования системы отношений человека с миром на протяжении всей его жизни. Однако именно для молодых людей в период с 18 до 26-27 лет утрата стабильности, устойчивых моделей идентификации, усиливающаяся неопределенность становятся серьезной проблемой для их психического здо- 
ровья, поскольку в этом возрасте они пытаются установить свои собственные уникальные отношения с миром, обретают социальную идентичность, ищут и апробируют модели личностно-средового взаимодействия.

Появление проблем в сфере межличностного функционирования, нарушения системы отношений и невротизация личности в молодом возрасте может рассматриваться, с одной стороны, как следствие воздействия негативных социально-психологических факторов, препятствующих удовлетворению актуальных потребностей личности, а с другой, - как один из источников социальной фрустрированности.

Необходимыми признаками фрустрационных ситуаций являются: наличие сильной мотивации удовлетворить потребность (достичь цели) и преграды, препятствующей этому стремлению. Образно говоря, фрустрация - это стресс «рухнувшей надежды» [5]. Упоминая о нарушениях личностно-средового взаимодействия, мы имеем ввиду особый вид фрустрации - социальную фрустрированность как форму психического напряжения, наступающего вследствие неудовлетворенности достижениями и положением личности в социальной иерархии [5]. Социальная фрустрированность обуславливает эмоциональное отношение личности к позициям, которые были ею заняты в обществе на текущий момент жизни [13], она связана с тем, как складывается реальная социальная ситуация, в которой живет и функционирует молодой человек. В качестве социальных фрустраторов (фрустрирующих факторов) часто выступают неудовлетворённость семейными и рабочими отношениями, уровнем образования, социально-экономическим статусом, местом, занимаемым в обществе, физическим и психическим здоровьем и др. Социальную фрустрированность можно рассматривать как специфический комплекс переживаний и отношений личности, возникающий в ответ на действие фрустрирующих факторов [7]. Она сопровождается негативными эмоциями и состояниями, которые могут быть следствием невозможности реализации личностью своих собственных социальных потребностей.

Социальная фрустрированность может приводить к развитию различной психической патологии, в том числе, невротических расстройств: «длительное дестабилизирующее действие социально фрустрирующих факторов формирует напряженность адаптивных механизмов и парциальную дезадаптацию (предболезнь), а при малоэффективной психологической защите и отсутствии социальной поддержки - тотальную психическую дезадаптацию (болезнь), и как следствие, снижение качества жизни» [14, с.4].

Изучение взаимосвязей невротических черт личности и уровня социальной фрустрированности было предпринято в последние годы в целом ряде работ $[1 ; 2$; 5; 10; 13; 17]. В частности, П.К. Тромбчиньски [17], выявил, что люди с невротическими расстройствами в большей степени, чем здоровые, испытывают социальную фрустрированность, а также, чем больше выраженность невротических черт личности, тем выше уровень фрустрированности. Согласно П.К. Тромбчиньски невротические расстройства связаны с нарушениями в межличностном функционировании, обусловлены неудовлетворенностью жизнью, социальной активностью, переживанием чувства вины, беспомощности и одиночества, повышенным чувством опасности, низкой мотивированностью, наличием проблем в межличностных отношениях, зависимостью от окружения, опасениями, связанными с вхождением в новые социальные ситуации.

Связь выраженности невротических состояний у молодых людей и уровня и особенностей их социальной фрустрированности освещена в научной литературе последних лет недостаточно. Поэтому одна из целей данной работы - показать существование связи между выраженностью различных невротических состояний у молодых людей и уровнем и особенностями их социальной фрустированности.

Исследование взаимосвязи социальной фрустрированности и невротизации тем более интересно применительно к так называемому «цифровому поколению», к которому можно отнести молодых людей 18-27 лет. Компьютер, мобильный телефон, различные цифровые устройства, интернет, социальные сети, IT-средства за последние десятилетия прочно вошли в жизнь респондентов данной возрастной группы, радикально изменив окружающий их мир. Наряду с привычной предметной средой и традиционной средой реальных социальных отношений, формируется параллельная «цифровая реальность», вне которой сегодня невозможно представить функционирование ни одной сферы жизни человека.

Одной из форм пребывания в цифровой реальности является пребывание в пространстве компьютерных игр. Компьютерные игры являются одной из самых противоречивых тем в современной психологии и вызывают дискуссии и споры среди ученых. С ними связывают множество возможных негативных эффектов, в том числе зависимость от компьютерных игр [16]. Компьютерные игры вошли в Международную классификацию болезней BO3; в пятой редакции DSM зависимость от онлайн-видеоигр значится в разделе явлений, нуждающихся в дополнительном изучении. Признание существования таких видов патологии как зависимость от компьютерных игр или же интернет-зависимости постулирует возможность возникновения принципиально новых форм психической патологии под влиянием цифровых технологий $[4 ; 14 ; 16]$. Однако имеет право 
на существование и противоположная точка зрения, согласно которой, цифровые технологии ведут лишь к патоморфозу хорошо известных психических расстройств, оказывая заметное влияние на их феноменологию, течение и поведенческие нарушения и, возможно, облегчая их возникновение.

В данном исследовании мы пытались выявить не только распространенность невротических состояний (неклинических, а также выраженных форм) у молодых людей, играющих в компьютерные игры и являющихся активными пользователями игровыми платформами (что явилось важным аспектом данной работы, поскольку официальная статистика, отражающая рост невротических расстройств в данной группе, практически отсутствует), но и проверить предположение о том, что респонденты, наиболее вовлеченные в компьютерные игры, выявляют более выраженные невротические состояния. Патоморфоз невротических состояний под влиянием цифровых технологий можно таким образом рассматривать как проявляющийся, в частности, в усилении выраженности невротических состояний у молодых людей с достаточно высокой степенью вовлеченности в компьютерные игры.

Увлеченность компьютерными играми имеет как ряд позитивных, так и негативных эффектов, при этом о негативном эффекте игр можно говорить только в случае чрезмерного злоупотребления ими при угрозе формирования интернет-зависимости как многомерного явления, включающего по мнению К. Янга [18, с. 26] проявления эскапизма - бегства в виртуальную реальность людей с низкой самооценкой, тревожных, склонных к депрессии, ощущающих свою незащищенность, одиноких или не понятых близкими, тяготящихся своей работой, учебой или социальным окружением; поиск новизны; стремление к постоянной стимуляции чувств; эмоциональную привязанность - возможность выговориться, быть эмпатийно понятым и принятым, освободиться от острого переживания неприятностей в реальной жизни, получить поддержку и одобрение; удовольствие ощутить себя «виртуозом» в применении компьютера и специальных поисковых либо коммуникативных программ.

Если же игры присутствуют в жизни человека как сопутствующий фактор, то, наоборот, их можно рассматривать как возможность развлекаться, развивать интеллект, навыки общения, компьютерную грамотность, а также они могут быть конкретным проявлением субъектного, здорового способа бытия, реализуя «игровое переживание», сущностными характеристиками которого является активное, спонтанное опробование себя и предмета игры; преобладание внутренней мотивации; удовольствие от процесса игры $[15$, с. 10]. Доказательством этого утверждения будет наличие среди активных пользователей игровыми платформами молодых людей, не выявляющих никаких невротических состояний, а также демонстрирующих относительно низкий уровень социальной фрустрированности.

\section{Методики исследования}

Определение распространенности различных невротических состояний у молодых людей осуществлялось с помощью «Клинического опросника для выявления и оценки невротических состояний» (К.К. Яхин, Д.М. Менделевич, [19]. Степень (уровень) и особенности социальной фрустрированности изучались с помощью «Методики диагностики уровня социальной фрустрированности Л.И. Вассермана (в модификация В.В. Бойко)» [6]. Для оценки увлеченности Интернет использовался тест К. Янг (разработанный в 1996 году для оценки интернет-зависимости, но потерявший свою актуальность), адаптированный В.А. Буровой [4].

\section{Описание выборки}

Определение распространенности различных невротических состояний у молодых людей, играющих в компьютерные игры, а также изучение связи степени выраженности данных состояний с характером и особенностями социальной фрустрированности, проводилось нами совместно с А.В. Козловым (студентом 6 курса факультета психологии РГГУ) на базе активных пользователей одного из игровых интернет-порталов. В исследовании приняли участие молодые люди в возрасте от 18 до 27 лет (средний возраст - 21 год). Всего 644 человека. Из них 358 (55,6\% выборки) респондентов женского и 286 (44,4\% выборки) мужского пола. На рисунке 1 показано процентное распределение испытуемых по возрасту.

\section{Результаты исследования.}

\section{1. Распространенность невротических состояний у активных пользователей игровыми интернет- порталами}

С помощью «Клинического опросника для выявления и оценки невротических состояний» (К.К. Яхин, Д.М. Менделевич) исследована распространенность и выраженность невротических состояний у молодых людей, активных пользователей игровых платформ: у 20,1\% респондентов не обнаружено признаков невротических состояний; у 79,9\% наблюдаются различные невротические состояния. У большинства молодых людей (61\%) невротические состояния носят ярко выраженный характер.

В большинстве случаев невротические состояния носят смешанный характер и сочетаются у одного и того же человека. В структуре невротических состояний наиболее часто доминируют (встречаются) невротическая 
депрессия $(47,6 \%)$ и обсессивно-фобические нарушения (33,2\%). Тревога как невротическое состояние, доминирует у $27,3 \%$ молодых людей, истерический тип реагирования - у 23,6\%, вегетативные нарушения - у 20,9\%, астения - у 18,6\%. «Чистые», не сочетанные невротические состояния встречаются редко: только тревога характерна для 7 респондентов, что составило 1,1\% выборки; только невротическая депрессия характерна для 84 респондентов, что составило 13\% всех опрошенных; только астения наблюдается у 5 респондентов, то есть 0,8\% от общего их числа; только истерический тип реагирования характерен для 7 респондентов, что составляет 1,1\% выборки; только обсессивно-фобические нарушения проявляются у 22 респондентов, что составляет 3,4\% выборки; только вегетативные нарушения проявляются у 8 респондентов, что составило 1,2\% всей выборки.

По результатам оценки степени выраженности невротических состояний у молодых людей, активных пользователей игровыми интернет-платформами, согласившихся принять участие в исследовании, все респонденты были разделены на три группы: 1 групnа - молодые люди без признаков невротических состояний («условно здоровые») - 133 человека; 2 групnа - молодые люди, со средней степенью выраженности невротических состояний - 118 человек; 3 групnа - молодые люди с яркими проявлениями (высокой степенью выраженности) невротических состояний- 393 человека.

\section{2. Результаты исследования увлеченности Интернет в группах молоАых ^юАей (активных пользователей игровыми интернет-порталами) с различными невротическими состояниями}

Согласно полученным данным, во всех группах наблюдается тенденция к обычному использованию Интернет. Ни у кого из «условно здоровых» молодых людей и молодых людей со средне выраженными невротическими состояниями не выявлена сильная увлеченность Интернет, а в группе с наличием невротических состояний доля сильной увлеченности Интернет составила только 1,5\%. При этом показатели увлеченности Интернет у «условно здоровых» молодых людей значительно ниже, чем в двух других сравниваемых группах $(p<0,01)$.

Результаты исследования связи выраженности невротических состояний со степенью увлеченности Интернет представленным в Таблице 1.

Получена значимая положительная связь выраженности всех невротических состояний со степенью увлеченности Интернет: чем выше степень увлеченности Интернет, тем более выражены невротические состояния, и чем более выражены невротические состояния, тем более выражена увлеченность Интернет.
Таблица 1.

Взаимосвязь выраженности невротических состояний со степенью увлечённости Интернет

(коэффициент корреляции Пирсона, $\mathrm{n}=644$ )

\begin{tabular}{|l|c|}
\multicolumn{1}{c|}{ Невротические состояния } & Увлеченность Интернет \\
\hline Тревога & $0,362^{* *}$ \\
\hline Невротическая депрессия & $0,459^{* *}$ \\
\hline Астения & $0,443^{* *}$ \\
\hline Истерический тип реагирования & $0,345^{* *}$ \\
\hline Обсессивно-фобические нарушения & $0,437^{* *}$ \\
\hline Вегетативные нарушения & $0,286^{* *}$ \\
\hline
\end{tabular}

$$
\text { ** }-p \leq 0,01, *-p \leq 0,05
$$

Наиболее тесная связь обнаружена между увлеченностью Интернет и выраженностью невротической депрессии, астении и обсессивно-фобических расстройств. Наименее связана с увлеченностью Интернет выраженность вегетативных состояний.

\section{3. Уровень и особенности сошиальной Фрустированности молодых ^юАей (активных пользователей игровыми интернет-порталами) с различными невротическими состояниями}

Сравнительный анализ степени социальной фрустированности молодых людей, вошедших в группы с различной выраженностью невротических состояний Выявил, что средний показатель общей социальной фрустрированности в группе молодых людей без проявлений невротических состояний, а также со средней выраженностью невротических состояний, достиг всего лишь уровня неопределенности; в группе респондентов с высокой выраженностью невротических состояний среднее значение общей социальной фрустрированности достигает повышенного уровня. Относительно низкий уровень социальной фрустрированности характерен только для условно здоровых молодых людей (без невротических состояний). Высокий и повышенный уровень социальной фрустрированности обнаруживают прежде всего респонденты с высокой выраженностью невротических состояний. Повышенный уровень социальной фрустрированности в группе респондентов с явно выраженными невротическими состояниями был выявлен по следующим шкалам опросника: в сфере отношений с близкими, в оценке своего экономического положения, в сфере оценки собственного здоровья, причем данных респондентов в наибольшей степени волнует (фрустрирует) состояние их собственного здоровья и работоспособность. Неудовлетворенность своими отношениями с социумом и своим социальным статусом оказалась не столь высока: ее оценка респондентами всех трех групп входит в группу неопределенности. 
Результаты сравнительного анализа степени социальной фрустированности молодых людей, вошедших в группы с различной выраженностью невротических состояний, представлены на Рисунке 2.

Респонденты с разной степенью выраженности невротических состояний были распределены по степеням (уровням) социальной фрустрированности. Результаты (смотри Рисунок 3) свидетельствуют, что все молодые люди, независимо от наличия и выраженности невротических состояний, в той или иной степени все же переживают социальную фрустрированность, поскольку ни у одного из участников исследования не выявлено ее полное отсутствие (нулевой уровень).
Для условно здоровых молодых людей характерен средний (неопределенный), умеренный и пониженный уровни социальной фрустрированности. Для респондентов с высокой степенью выраженности невротических состояний значения социальной фрустрированности смещаются в сторону умеренных, повышенных и высоких ее значений. Распределение респондентов со средней выраженностью невротических состояний повторяет распределение условно здоровых молодых людей.

Результаты оценки статистической значимости различий в степени социальной фрустрированности в группах молодых людей с различной выраженностью

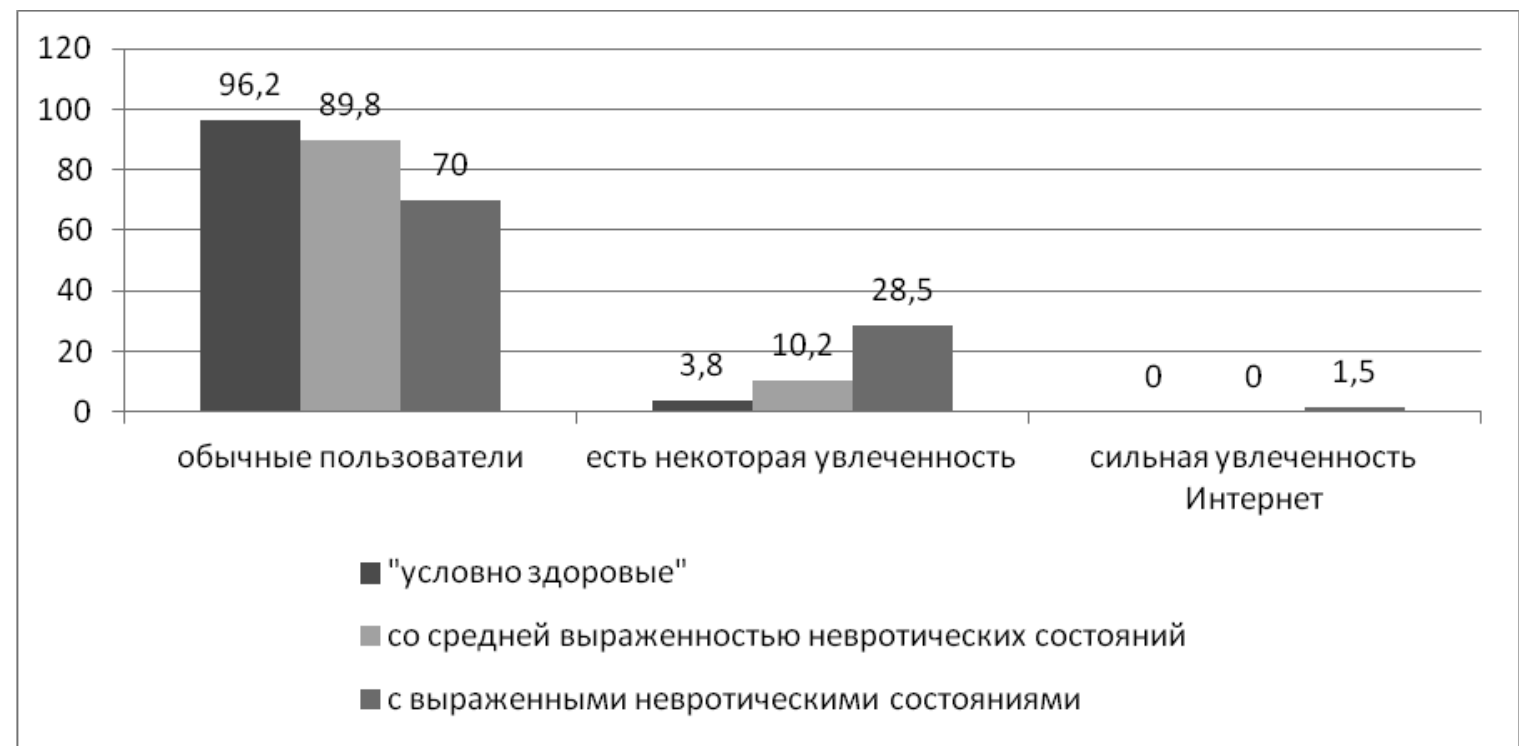

Рис. 1. Процентное соотношение молодых людей с разной степенью увлеченности

Интернет в группах с различной выраженностью невротических состояний (\%)

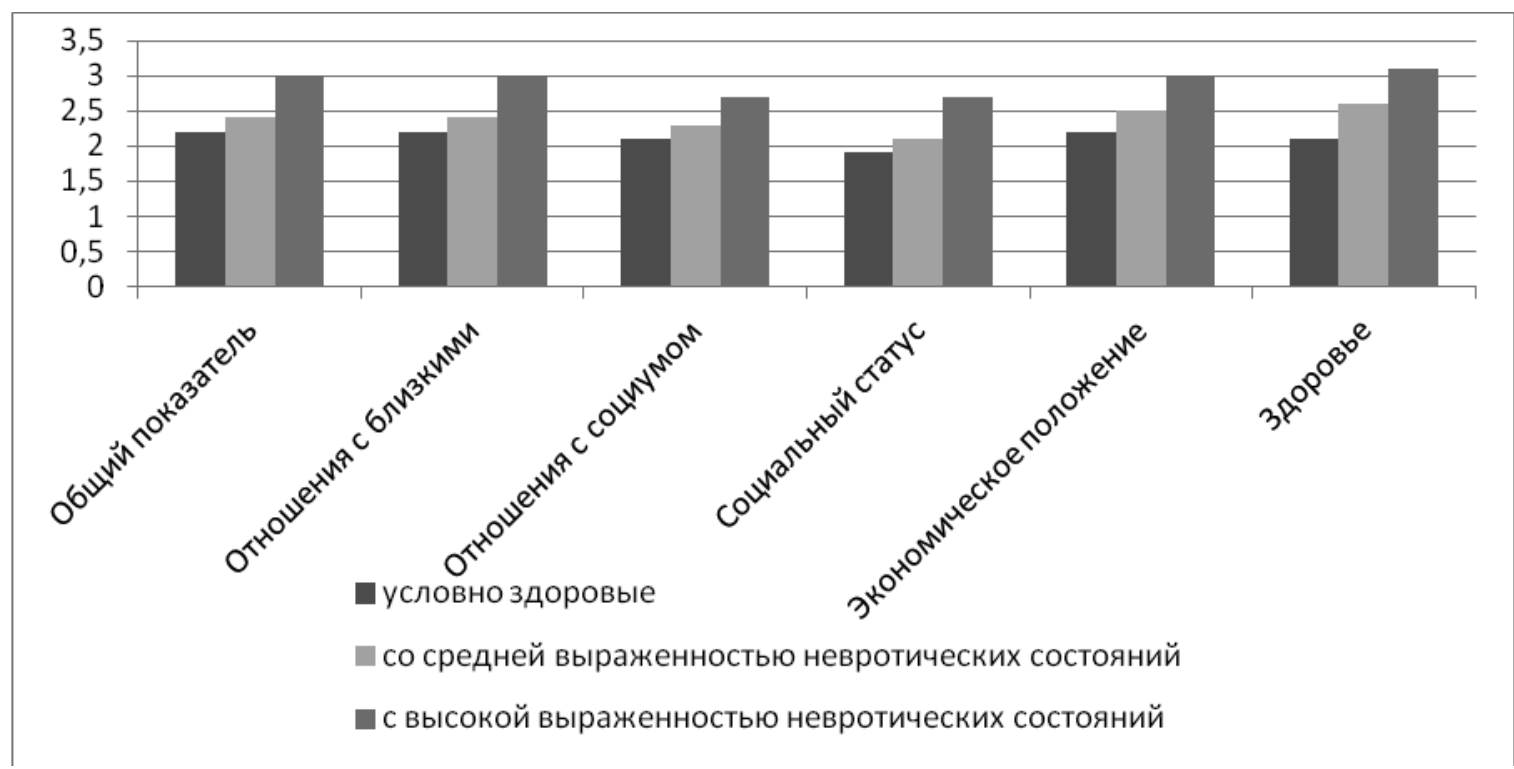

Рис. 2. Показатели социальной фрустрированности (средний балл) в группах молодых людей с различной выраженностью невротических состояний 


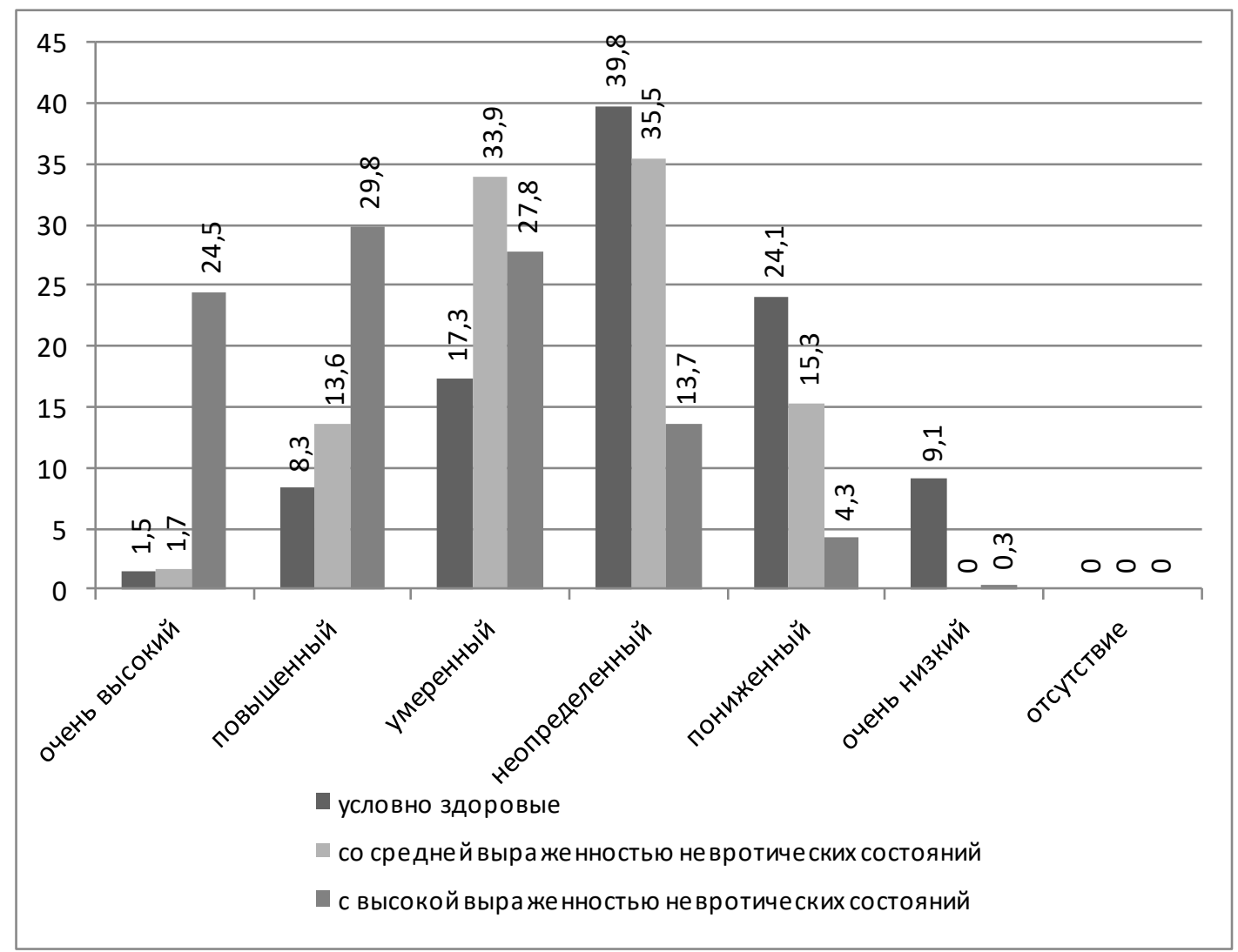

Рис. 3. Распределение респондентов с разной степенью выраженности невротических состояний по группам с разным уровнем социальной фрустрированности (\%)

невротических состояний (независимо от их характера), свидетельствуют о том, что наиболее значимые различия между группами условно здоровых респондентов и респондентов со средней выраженностью обнаружены по шкалам «здоровье и работоспособность», а также по общему индексу социальной фрустрированности. Та же тенденция выявляется и при сравнении групп молодых людей с высокой выраженность невротических состояний и условно здоровых. Молодые люди с явно выраженными невротическими состояниями по сравнению со здоровыми выявляют статистически значимо большую неудовлетворенность всеми сферами своих отношений с миром - взаимоотношениями с близкими, отношениями с социальным окружением, своим социальным статусом, экономическим положением, здоровьем и работоспособностью. При этом неудовлетворенность собственным здоровьем и работоспособностью, как уже отмечалось выше, выходит на первый план. Они обнаруживают также статистически значимые различия в уровне социальной фрустрированности по сравнению с респондентами с невыраженными невротическими состояниями («условно здоровыми»): уровень их социальной фрустрированности значимо выше. Была также определена статистическая значимость различий в частоте встречаемости разных уровней социальной фрустрированности в группах с разными невротическими состояниями. Результаты отражены в Таблице 2. Согласно полученным в исследовании данным, респонденты со средней выраженностью невротических состояний все же отличаются по частоте встречаемости различных уровней социальной фрустрированности от условно здоровых респондентов, причем различия имеют характер тенденции $(p \leq 0,05)$. Последние чаще имеют очень низкий и умеренный уровни социальной фрустрированности. Наиболее статистически значимо различаются группы условно здоровых респондентов и респондентов с высокой степенью выраженности невротических состояний. У последней группы респондентов значимо чаще встречается очень высокий и повышенный уровни социальной фрустрированности и реже встречается пониженный и низкий ее уровни.

Результаты анализа взаимосвязи выраженности невротических состояний и уровня социальной фрустрированности представлены в Таблице 3.

Наиболее высок коэффициент корреляции общего показателя социальной фрустрированности с выраженностью невротической депрессии $\left(0,674^{* *}\right)$, на втором месте - величина коэффициента корреляции данного показателя с астеническими состояниями; на третьем месте - величина коэффициента корреляции уровня 
Таблица 2.

Значимость различий в частоте встречаемости различных уровней социальной фрустрированности в группах с разными невротическими состояниями

\begin{tabular}{|c|c|c|c|}
\hline \multirow[b]{2}{*}{ 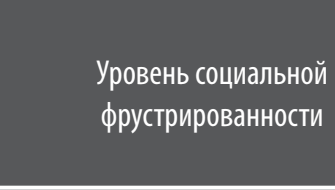 } & \multicolumn{3}{|c|}{ X2-критерий Пирсона } \\
\hline & $\begin{array}{c}\text { «Здоровые»/Со средней } \\
\text { выраженностью НС } \\
\text { (n1=133, n2=118) }\end{array}$ & $\begin{array}{c}\text { «Здоровые»/С высокой } \\
\text { выраженностью НС } \\
\text { (n1=133, n2=393) }\end{array}$ & $\begin{array}{c}\text { Со средней выраженностью НС / } \\
\text { С высокой выраженностью НС } \\
\text { (n1=118, n2=393) }\end{array}$ \\
\hline очень высокий & - & $21,389^{* *}$ & $20,872^{* *}$ \\
\hline повышенный & 0,948 & $13,626^{* *}$ & $6,8^{* *}$ \\
\hline умеренный & $6,39^{*}$ & 2,582 & 0,61 \\
\hline неопределенный & 0,232 & $16,672^{* *}$ & $12,036^{* *}$ \\
\hline пониженный & 1,922 & $14,506^{* *}$ & $5,656^{*}$ \\
\hline очень низкий & $6,364^{*}$ & $4,984^{*}$ & - \\
\hline отсутствие & - & - & - \\
\hline
\end{tabular}

$* *-p \leq 0,01, *-p \leq 0,05$

Таблица 3.

Взаимосвязь выраженности различных невротических состояний и социальной фрустрированности

\begin{tabular}{|l|c|c|c|c|c|c|}
\multirow{2}{*}{\multicolumn{1}{c}{ Невротические состояния }} & \multicolumn{7}{c|}{ Показатели социальной фрустрированности } \\
\cline { 2 - 7 } & 0 & 01 & 02 & 03 & 04 & 05 \\
\hline Тревога & $0,440^{* *}$ & $0,266^{* *}$ & $0,387^{* *}$ & $0,302^{* *}$ & $0,229^{* *}$ & $0,493^{* *}$ \\
\hline Невротическая депрессия & $0,674^{* *}$ & $0,456^{* *}$ & $0,564^{* *}$ & $0,421^{* *}$ & $0,456^{* *}$ & $0,666^{* *}$ \\
\hline Астения & $0,524^{* *}$ & $0,272^{* *}$ & $0,444^{* *}$ & $0,385^{* *}$ & $0,321^{* *}$ & $0,559^{* *}$ \\
\hline Истерический тип реагирования & $0,437^{* *}$ & $0,266^{* *}$ & $0,379^{* *}$ & $0,285^{* *}$ & $0,287^{* *}$ & $0,445^{* *}$ \\
\hline Обсессивно-фобические нарушения & $0,439^{* *}$ & $0,245^{* *}$ & $0,402^{* *}$ & $0,310^{* *}$ & $0,263^{* *}$ & $0,466^{* *}$ \\
\hline Вегетативные нарушения & $0,377^{* *}$ & $0,184^{* *}$ & $0,293^{* *}$ & $0,219^{* *}$ & $0,183^{* *}$ & $0,407^{* *}$ \\
\hline
\end{tabular}

** $-p \leq 0,01, *$ - $p \leq 0,05$

Показатели социальной фрустрированности: Q - Социальная фрустрированность (общий индекс); Q1- Bзаимоотношения с близкими; Q2 - Отношения с социальным окружением; Q3 - Социальный статус; Q4 - Экономическое положение; Q5 - Здоровье, работоспособность.

социальной фрустрированности с выраженностью тревожных состояний $\left(0,440^{* *}\right)$, истерического типа реагирования $\left(0,437^{* *}\right)$, выраженностью обсессивно-компульсивных расстройств $\left(0,439^{* *}\right)$. Наименее тесно связаны с социальной фрустрированностью вегетативные нарушения $\left(0,377^{* *}\right)$, хотя и эта связь является высоко значимой $(p \leq 0,01)$.

Для того, чтобы определить как связаны социальная фрустрированность (ее общий показатель, а также уровень фрустрированности потребностей в различных сферах жизни) с выраженностью различных невротических состояний (невротической депрессии, невротической тревоги, астенических состояний, истерического типа реагирования, обсессивно-компульсивных расстройств и вегетативные нарушения) было проведено ранжирование величины коэффициентов корреляции, представленных в Таблице 2. Результаты ранжирования отражены в Таблице 4.
Согласно полученным данным наиболее тесная связь обнаруживается между выраженностью всех исследуемых невротических состояний (за исключением невротической депрессии) с неудовлетворенностью своим здоровьем и работоспособностью. Эта связь даже более тесная нежели связь выраженности различных невротических состояний с общим показателем социальной фрустрированности (2-ой ранг). На третьем месте (3-ий ранг) - взаимосвязь выраженности всех исследуемых невротических состояний с неудовлетворённостью молодых людей своими отношениями с социальным окружением. На последнем месте (6-ой ранг) - степень связи выраженности большинства исследуемых невротических состояний (кроме невротической депрессии и тревоги) со степенью неудовлетворённости молодых людей своими отношениями с близкими. Тревожные респонденты наименее фрустрированы своим экономическим положением, а на предпоследнем 5-ом месте для этого типа расстройств находится озабоченность своими от- 
Таблица 4.

Результаты ранжирования коэффициентов корреляций выраженности невротических состояний со степенью выраженности показателей социальной фрустрированности.

\begin{tabular}{|c|c|c|c|c|c|c|}
\hline \multirow{2}{*}{ Невротические состояния } & \multicolumn{6}{|c|}{ Ранги величины коэффициентов корреляций } \\
\hline & 1 & 2 & 3 & 4 & 5 & 6 \\
\hline Тревога & Q5 & Q & Q2 & Q3 & Q1 & Q4 \\
\hline Невротическая депрессия & $Q$ & Q5 & Q2 & $Q 1=04$ & $Q 1=04$ & Q3 \\
\hline Астения & Q5 & Q & Q2 & Q3 & Q4 & Q1 \\
\hline Истерический тип реагирования & Q5 & Q & Q2 & Q4 & Q3 & Q1 \\
\hline 0бсессивно-фобические нарушения & Q5 & $Q$ & Q2 & Q4 & Q3 & Q1 \\
\hline Вегетативные нарушения & Q5 & Q & Q2 & Q3 & $01=04$ & $Q 1=04$ \\
\hline
\end{tabular}

Показатели социальной фрустрированности: Q - Социальная фрустрированность; Q1- Взаимоотношения с близкими; Q2 - Отношения с социальным окружением; Q3 - Социальный статус; Q4 - Экономическое положение; Q5 - 3доровье, работоспособность.

ношениями с близкими.

Молодые люди с депрессивными состояниями демонстрируют наиболее высокую степень связи выраженности невротической депрессии с общим показателем социальной фрустрированности. В то же время они наименее фрустрированы неудовлетворенностью своим экономическим положением. Как правило 4-ое и 5-ое место (средняя позиция) занимает теснота связей выраженности всех невротических состояний с неудовлетворенностью своим социальным статусом и экономическим положением.

\section{ОбсужАение результатов и выводы}

Результаты изучения невротических состояний у молодых людей, активных пользователей игровыми интернет-порталами выявили негативную тенденцию. Только пятая часть молодых людей $(20,1 \%)$ не имеет признаков невротических состояний, тогда как у остальных 79,9\% наблюдаются различные невротические состояния, причем у большинства молодых людей (61\%) выявлен болезненный их характер. В структуре невротических состояний у молодых людей наиболее часто встречаются невротическая депрессия и обсессивно-фобические нарушения. Реже всего встречается астения. В большинстве случаев невротические состояния носят смешанный характер и сочетаются у одного и того же человека.

Исследование позволило также проверить предположение о том, что респонденты, наиболее вовлеченные в компьютерные игры, выявляют более выраженные невротические состояния. Данное предположение нашло свое подтверждение. Даже несмотря на то, что 70\% молодых людей с высокой выраженностью невротических состояний определили себя как «обычных пользователей интернет», выраженная (28,5\%) и сильная увлеченность Интернет (1,5\%) характерна лишь для пользовате- лей с высокой степенью выраженности невротических состояний.

Таким образом, формирование интернет-зависимости, включающее в себя проявления эскапизма - бегства в виртуальную реальность, согласно нашим исследованиям характерна лишь для 1,5\% активных пользователей игровыми интернет - платформами. В этом случае, по всей вероятности, можно говорить о том, что либо мы имеем дело именно с новым видом патологии - интернет-зависимостью, либо сталкиваемся с патоморфозом игровой зависимости, связанной с нарушением влечений и известной с древнейших времен.

Полученные в исследовании результаты также свидетельствуют о том, что патоморфоз невротических состояний под влиянием цифровых технологий можно рассматривать, в частности, как проявляющийся в усилении выраженности невротических состояний у молодых людей с достаточно высокой степенью вовлеченности в компьютерные игры. Наиболее тесная связь обнаружена между увлеченностью Интернет и выраженностью невротической депрессии, астении и обсессивно-фобических расстройств. Наименее связана с увлеченностью Интернет выраженность вегетативных состояний.

В то же время «условно здоровые» респонденты вообще не обнаружили сильной увлеченности Интернет (0\%), а выраженное увлечение Интернет характерно лишь для 3,8\% «условно здоровых». По всей вероятности, в их жизни игры присутствуют как сопутствующий фактор, как возможность развлекаться, развивать интеллект, навыки общения, компьютерную грамотность, а также как здоровый способа бытия, реализующий «игровое переживание».

Полученные результаты не только подтверждают важность изучения проблемы невротических состоя- 
ний у молодых людей, активных пользователей игровыми интернет-порталами, но и позволяют соотнесении частоту встречаемости невротических состояний с исследованием социальной фрустрированности, что выявляет интересный факт, что невротические депрессивные состояния не только наиболее часто встречаются в структуре невротических расстройств, но их выраженность оказывается наиболее тесно связанной (по сравнению с выраженностью других невротических состояний) с общим индексом социальной фрустрированности $(0,674)$, с неудовлетворенностью своим здоровьем и работоспособностью $(0,666)$, а также отношениями со своим социальным окружением $(0,564)$. Именно респонденты с невротической депрессией демонстрируют наиболее высокий уровень неудовлетворенности взаимоотношениями с близкими, своим социальным статусом и экономическим положением. На втором месте по тесноте связей с уровнем социальной фрустрированности находится выраженность астенических состояний $(0,524)$, которые также в наибольшей степени связанны с неудовлетворенностью своим здоровьем и работоспособностью $(0,559)$, но, в то же время, наименее распространенные (наименее характерны) в выборке молодых людей, активных пользователей игровыми платформами. Данный факт свидетельствует прежде всего о том, что несмотря на невысокую частоту встречаемости, астенические состояния, если они и проявляются, то степень их выраженности (тяжесть состояния) связана с социальной фрустрированностью. Наименее тесно связаны с социальной фрустрированностью вегетативные нарушения $(0,377)$, хотя и эта связь является высоко значимой $(p \leq 0,01)$.

Исследование социальной фрустрации также показало, что она в разной степени переживается всеми молодыми людьми - активными пользователями игровыми интернет-платформами независимо от наличия у них невротических состояний. Однако если у большинства «условно здоровых» респондентов и с неявно выраженными невротическими состояниями молодых людей ее уровень не превышает умеренного, то у молодых людей с выраженными невротическими состояниями он чаще очень высокий или повышенный. Молодые люди с невротическими состояниями (активные пользователи игровыми интернет-платформами), независимо от выраженности последних, отличаются более высоким уровнем социальной фрустрированности, в сравнении с «условно здоровыми» молодыми людьми.

Согласно полученным данным наиболее тесная связь обнаруживается между выраженностью всех исследуемых невротических состояний (за исключением невротической депрессии, выраженность которой наиболее тесно связана, как отмечалось выше, с общим индексом социальной фрустрированности) с неудовлетворенностью своим здоровьем и работоспособностью. Эта связь даже более тесная нежели связь выраженности различных невротических состояний с общим показателем социальной фрустрированности. На последнем месте (согласно величине корреляционной связи) обнаруживается степень связи выраженности большинства исследуемых невротических состояний (кроме невротической депрессии и тревоги) со степенью неудовлетворённости молодых людей своими отношениями с близкими.

Таким образом полученные данные позволили выявить связь конкретных фрустрирующих факторов со степенью выраженности различных невротических состояний, среди которых здоровье и работоспособность выступают на первый план. Отметим, что поскольку исследование проводилось до начала пандемии (конец 2018 - начало 2019 г.г.), мы не можем рассматривать ее как фактор, определяющий неудовлетворенность своим здоровьем и работоспособностью. При этом снижение плотности связи выраженности невротических состояний со степенью неудовлетворённости молодых людей (активных пользователей игровыми интернет-порталами) своими отношениями с близкими, по всей вероятности, отражает снижение ценности этих отношений в общей структуре ценности молодежи. Ранжирование степени тесноты связей выраженности невротических состояний с уровнем социальной фрустрированности позволяет судить о значимости фрустрирующих факторов для молодых людей. Иначе говоря, мы выявляем определенную структуру ценностный ориентаций данной группы респондентов: на первое место выходит значимость собственного здоровья и работоспособности, на второе - отношения с социальным окружением, третье и четвертое делят социальный статус и собственное экономическое положение, а последнее - отношения с близкими.

\section{ЛИТЕРАТУРА}

1. Айварова Н.Г., Наумова М.В. Актуальные вопросы психологического здоровья современной студенческой молодежи // Азимут научных исследований: педагогика и психология. 2017. Т. 6. № 4(21) С. 266-269.

2. Айварова Н.Г., Шимельфених А.Р. Факторы психологического здоровья молодежи // Вестник югорского государственного университета. 2017 г. Выпуск 1 (44). С. 19-24.

3. Александровский Ю.А. Пограничные психические расстройства. М.: Медицина, 2000 
4. Бурова В.А. Интернет-зависимость в медицинской парадигме // Интернет-зависимость: психологическая природа и динамика развития / сост. и ред. А.Е. Войскунский. — Москва: Акрополь, 2009. С. 152-164.

5. Вассерман Л.И., Дубинина Е.А. Социальный стресс и здоровье // Руководство по психологии здоровья / Под ред. А.Ш. Тхостова, Е.И. Рассказовой. - Издво Московского университета, 2019. С. 363-392.

6. Вассерман Л.И., Щелкова 0.Ю. Психологическая диагностика расстройств эмоциональной сферы и личности: Коллект. моногр. СПб.: Скифия-принт, 2014.

7. Демидова Т.Н. Проблемы виртуального общения в современном обществе как индикатор психологического неблагополучия личности // Психологическое здоровье личности: теория и практика: сборник научных трудов по материалам III Всероссийской научно-практической конференции / отв. ред. И. В. Белашева. Ставрополь: Изд-во СКФУ, 2016. С. 48-49.

8. Дубовская Е.М. Транзитивность общества как фактор социализации личности [Электронный ресурс] // Психологические исследования. 2014. Т. 7. № 36. C. 7. URL: http://psystudy.ru (дата обращения: 6.06.2019).

9. Козлов В.Е., Тимофеев А.А., Садрисламов Г.Ф. Развитие личности в современных условиях: социально-педагогический аспект // «Развитие человека в эпоху цифровизации»: сборник научных трудов; под редакцией д.п.н., профессора Р.Х. Гильмеевой, к.п.н., доцента Л.А. Шибанковой в 2-х томах, том 1. Казань: Институт педагогики, психологии и социальных проблем, 2020. С. 200-206.

10. Козловская Л.И. Невроз как проявление адаптации в социуме за счет ближайшего окружения // Неврозы в современном мире. Новые концепции и подходы к терапии: сборник тезисов научно-практической конференции с международным участием, 3-4 февраля 2011 г., Санкт-Петербург / Под общей ред. Н.Г. Незнанова и Б.Д. Карвасарского. - СПб.: СПб НИПнИ им. В.М. Бехтерева, 2011. С. 82-83.

11. Марцинковская Т.Д. Информационное пространство транзитивного общества: проблемы и перспективы развития // Консультативная психология и психотерапия. 2019. Т. 27. № 3. С. 77-96. doi: 10.17759/срр.2019270306

12. Марцинковская Т.Д. Проблема социализации в историко-генетической парадигме. М.: Смысл, 2015. 247 с

13. Осипова Н.В. Психическое здоровье личности в условиях современного общества // Психологическое здоровье личности: теория и практика: сборник научных трудов по материалам III Всероссийской научно-практической конференции / отв. ред. И.В. Белашева. Ставрополь: Изд-во СКФУ, 2016. С. 102103.

14. Рассказова Е.И., Емелин В.А., Тхостов А.Ш. Диагностика психологических последствий влияния информационных технологий на человека: учеб.-метод. пособие для студ. психологических специальностей. М.: Акрополь, 2015. 115 с.

15. Сериков А.В. Психологическое благополучие личности в современном мире // Психологическое благополучие современного человека [Электронный ресурс]: материалы Международной заочной научно-практической конференции (20 марта 2019 г.) / Урал. гос. пед. ун-т; отв. ред. С.А. Водяха. - Электрон. дан. - Екатеринбург: [6. и.], 2019. - 1 электрон. опт. диск (CD-ROM). С. 9-13.

16. Солдатова Г.У., Рассказова Е.И., Нестик Т.А. Цифровое поколение России: компетентность и безопасность. М.: Смысл, 2017. 375 с.

17. Тромбчиньски П.К. Взаимосвязь невротических черт личности и уровня социальной фрустрированности // Вестник Санкт-Петербургского университета. Серия 16. Психология. Педагогика, 2016. Вып. 3.С. 126-139.

18. Янг К.С. Диагноз - интернет-зависимость // Мир Интернет. №2. 2000. С. 24-29.

19. Яхин К.К., Менделевич Д.М. Клинический опросник для выявления и оценки невротических состояний / Клиническая и медицинская психология: Практическое руководство. М., 1998. С.545-552.

(с)Шевеленкова Татьяна Дмитриевна (shevelenkova@gmail.com)

Журнал «Современная наука: актуальные проблемы теории и практики» 